\title{
Exports and Governance: is Middle East and North Africa different?
}

\author{
InmaculadaMartínez-Zarzoso ${ }^{1,2}$ and Laura Márquez-Ramos ${ }^{2,3}$
}

${ }^{1}$ Department of Economics, Georg-August University of Goettingen, Goettingen, Germany ${ }^{2}$ Department of Economics and Institute of International Economics, Universitat Jaume I, Castell on de la Plana, Spain ${ }^{3}$ Institute for International Trade, University of Adelaide, Adelaide, Australia

Pre-print version, forthcoming in The World Economy, 2018

\begin{abstract}
This paper aims to analyse whether a higher quality of economic governance rewards economic performance and facilitates the integration of the Middle East and North Africa region into the world economy. A gravity model of trade augmented with governance indicators is estimated using bilateral exports among 189 trading partners, including 19 MENA exporters, over the period from 1996 to 2013. The main results indicate that each of the six governance indicators have a positive effect on bilateral trade. However, the results for MENA exporters slightly differ. Governance in the importing countries seems to be less relevant for MENA exporters than for other exporters. The effect of country-pair similarity in governance indicators suggests that a similar level of regulatory quality and the rule of law in exporting and importing countries favours the exports of MENA countries. Similarities in voice and accountability also foster exports for the average exporter, but it does not seem relevant for MENA exporters.
\end{abstract}

\section{JEL Classification: F10, F14}

Keywords: exports, governance, MENA, gravity model, panel data

Acknowledgments: This research was funded by FEMISE grant No FEM41-08. 


\section{Exports and Governance: is Middle East and North Africa different?}

\section{Introduction}

The business environment in which firms develop their activities not only affect their productivity, but also the aggregate performance of the whole economy. The theoretical literature identifies differences in institutions as one of the key sources of cross-country differences in income and economic growth. It has been argued that broadly defined institutional barriers increase the cost of technology adoption and hence reduce longterm income per capita. The literature also suggests that the relationship is not necessarily linear and monotonic. Indicators of institutional quality commonly used in empirical research are: governance (World Bank Governance Indicators), regulatory constraints (Djankov et al., 2002; Botero et al. 2004), the level of economic freedom (Doyle and Martínez-Zarzoso, 2011) and property rights (Hall and Jones, 1999), among others. However, these studies usually estimate the association between the features of the business environment and macroeconomic performance rather than identifying the causal effects. Acemoglu et al. (2001) try to establish a causal relationship by using the mortality rates of European colonialists as an instrument for current institutions in an attempt to further separate the effects of property rights institutions from that of contracting institutions. They find that the former has a first-order effect on performance, while the latter matters only through their impact on financial intermediation.

The quality of institutions is not only a first-order determinant of economic development, but it also has a direct effect on trade flows among countries (Levchenko, 2007; Milner and Mukherjee, 2009; Nunn and Trefler, 2013; Berden et al., 2014; Horsewood and Voicu, 2012). In general, there is robust evidence indicating that democracy and good institutions foster trade. Nevertheless, there is only one study that 
goes beyond examining just "democracy" and focuses on governance and on single indicators that capture different dimensions of the institutional process and its effect on trade flows (Berden et al., 2014). Berden et al. (2014) evaluates a very short period of time (1998-2004) and focuses mainly on OECD exporters. In this paper, we claim that single governance indicators might affect trade cost differently and some of them could be more relevant for developing countries than for the rest. We advance this line of research by using up-to-date econometric techniques that will allow us to disentangle issues in causality (Gylfason et al., 2015). More specifically, the present research aims to analyse whether a higher quality of economic governance rewards countries economic performance with larger bilateral trade flows. We focus on the Middle East and North Africa (MENA) countries and compare the effects with other regions in the world economy. To the best of our knowledge, there have only been two studies that also focus on MENA countries, namely Méon and Khalid Sekkat (2004) and Ali and Mdhillat (2015). The former focuses on the effect of institutional quality on trade in MENA countries in the 1990s using openness as a dependent variable and political risk as a proxy for the quality of institutions; whereas, the later uses a gravity model approach using data in the 2000s but only focuses on corruption. We depart from these studies on two fronts. First, we use the World Bank Worldwide Governance Indicators (WGIs) and their various dimensions to investigate their specific effect on trade. Secondly, we also investigate whether similarities in governance indicators between countries affect trade flows using a newly developed fuzzy index and apply the model to the most recent data. This allows us to account for the changes that occurred after the Arab Spring.

The main results show that individually, each of the six governance indicators in the exporting and the importing countries considered, have a positive effect on bilateral 
trade. However, the results for MENA exporters differ slightly. Governance in the importing countries seems to be less relevant for MENA exporters than for other exporters. Increasing country-pair similarity in governance indicators -in terms of the levels of regulatory quality and the rule of law in the exporting and importing countries- favours the exports of MENA countries. Meanwhile, similarities in voice and accountability also foster exports for the average exporter, but it does not seem relevant for MENA exporters.

The main economic policy implications are that prerequisites for a good business environment at the country-level are the protection of property rights, a well-established rule of law, efficient bureaucracy and a corruption-free government. Improved governance in MENA countries, is therefore a must to foster a favourable business climate and enter a path of economic development and integration into the world economy. Moreover, the results indicate that similar levels of regulatory quality and rule of law, favour the exports of MENA countries, hence trade policies directed to liberalize trade could focus on trading partners with similar governance standards for those governance indicators.

The rest of the paper is structured as follows: Section 2 describes the background and specifies the empirical model. Section 3 describes the data and variables and presents the descriptive statistics. Section 4 presents the main results. Finally, section 5 concludes.

\section{Background and Related Literature}

The role and importance of institutions has been examined extensively in the economic literature (La Porta et al., 1997 and 1998; and Acemoglu et al., 2001, 2002, 2003). Most authors find that institutions matter for economic performance and that the findings are 
different across Northern and Southern outcomes. Easterly (2001) explains that the basic institutional requirements to facilitate economic performance include the protection of property rights, rule of law, efficient bureaucracy, corruption-free government and political constraint on the executive's behalf. Rather than being defined as 'proximate determinants' of economic growth, investment in physical and human capital offer a potential for growth that without supporting institutions -the ultimate causes of growth- cannot be exploited. Over several studies, Acemoglu et al. (2001, 2002, 2003) identify that weak institutional quality causes lower per capita income and higher macroeconomic volatility. They mainly focus on the historically determined component of institutions and do not address the potential contributory role of trade on macroeconomic outcomes. Some authors consider institutions to be a more significant explanatory variable than geography, the rationale being that once the impact of institutions is included, geography adds little to explaining cross-country differences in income as a finding and therefore at odds with the conclusion of the supremacy of geography in Sachs and Warner $(1995,1999,2001)$.

A strand of the literature, more closely related to this paper, considers institutional quality as a first-order determinant of trade flows (Levchenko, 2007; Milner and Mukherjee, 2009; Nunn and Trefler, 2013; Berden et al., 2014; Horsewood and Voicu, 2012. Levchenko (2007) proposed a model in which institutional differences are modelled within the framework of incomplete contracts. In this framework, those differences are a source of comparative advantage. The author tests the model using US imports and finds that institutional differences are an important determinant of trade flows. Milner and Mukherjee (2009) present a literature review of the interactions between democracy and globalization, mainly focusing on trade and capital account openness. They conclude that there is generally robust evidence indicating that 
democracy fosters trade and capital account liberalization, but that empirical support for the predicted positive effect of economic openness on democracy among developing countries is weak.

Nun and Trefler (2013) review the theoretical and empirical literature supporting the view that domestic institutions can have a profound effect on international trade. They also argue that institutional sources of comparative advantage are quantitatively as important as traditional sources and that they operate through fundamentally different channels.

Berden et al. (2014) used the WGIs to estimate the effects of governance on trade and foreign direct investment (FDI) using a state-of-the-art gravity model. Their data is restricted to the period from 1997 to 2004 and to 28 OECD countries as source countries and 124 potential destination countries, mainly due to the lack of FDI data. However, the WGIs are only available for 5 out of the 8 periods. They point to the problem of collinearity among the single indicators and for this reason add each of them sequentially. Berden et al. (2014) do not take into account exporters' governance indexes and for the sample of importers they also group the WGIs into three main components: the process by which governments are selected, monitored and replaced (this indicator includes voice and accountability and political stability), the capacity of the government to effectively formulate and implement sound policies (measured with government effectiveness and regulatory quality) and the respect of citizens and the state for institutions that govern economic and social interactions (comprising rule of law and the control of corruption). They hypothesize that the first category of indicators in the importing country has a negative effect on trade flows, whereas the other two positively affect exports. Their main results concerning trade flows show that whereas 
voice and accountability is negatively related to trade levels, a positive and statistically significant effect is obtained for the other five WGI variables individually. Horsewood and Voicu (2012) investigate the role of corruption on bilateral trade. These authors find that corruption hinders trade, although the difference between the ethical standards of the importing and exporting country has a negative impact on international transactions. Therefore, one must account for the business cultures of both an exporter and importer. Specifically, countries with a similar ethical business environment will tend to trade more with each other, suggesting that a shared understanding of what is considered an acceptable practice, is an important factor in cross-border transactions. Concerning literature that investigates the effect of institutional quality on trade in specific regions or with regards to specific levels of development, we find only two studies that focus on developing countries (Milner and Kubota, 2005 and Yu, 2010) and two studies that focus on the MENA region (Méon and Sekkat, 2004, and Ali and Mdhillat, 2015).

Milner and Kubota (2004) find that the emergence of democracy has a positive and significant effect on trade openness in developing countries, meanwhile $\mathrm{Yu}$ (2010) obtains similar findings, with the exception of the export of labour intensive goods from least developed countries to developed countries. In this specific case, he finds that an importer's level of democracy has a negative effect on exports. The theoretical explanation for this finding is based on the Stolper-Samuelson effect.

Focusing on MENA countries, Méon and Sekkat (2004) examine whether illfunctioning institutions disable a greater participation of these countries in the world economy. These authors examine the effect of country risk on both export performance and FDI attractiveness in the 1990s using country-level data for openness and applying panel data methods. The findings indicate that deteriorating institutional quality is 
generally associated with low performance in terms of manufactured exports and investment attractiveness.

More recently, Ali and Mdhillat (2015) confirm the negative effect of corrupt behaviour on international trade found by Horsewood and Voicu (2011) for Eastern European countries. They find that corruption hinders trade within the European Union but it has a more pronounced impact in MENA countries. Additionally, these authors also find that similarities in the ethical business environment between trading partners, increases the volume of trade.

Also focusing on MENA countries, the present research aims to analyse whether a higher quality of economic governance and similarities in the quality of governance, have an impact on bilateral trade flows. We compare the outcomes for all exporters with those for MENA exporters, using a longer period than Méon and Khalid Sekkat (2004) and Ali and Mdhillat (2015) and a larger sample of countries. Moreover, we consider a broad spectrum of governance indicators than this last paper, which only relies on corruption.

\section{Main Hypotheses and Model Specification}

Similar to a wide range of recent empirical studies that investigate the determinants of bilateral trade flows (Head and Mayer, 2014), we use the gravity model of trade, augmented with governance indicators, to determine its relative importance and to test a number of hypotheses derived from economic theory. The main reason for this selection is that the model provides a good statistical fit for most data sets and could be extended with policy variables. ${ }^{1}$

We hypothesize that single governance indicators could have a differential effect on trade and that it is not only governance in the importing country that matters for

\footnotetext{
${ }^{1}$ For a review of the literature using gravity models applied to trade flows, see Anderson (2010) and Martínez-Zarzoso (2013).
} 
exporters (as considered in Bergen et al., 2014), but also governance in the exporting country. Therefore, the gravity model will be augmented with governance indicators in the exporting and the importing country, separately. In addition, we also hypothesize that similarities in governance structures, in particular concerning regulatory quality, rule of law and the control of corruption, could also influence exports (Horsewood and Voicu, 2012; Levchenko, 2007) and hence similarity measures will be added as additional regressors in the gravity model.

Finally, concerning the direction of the effects, although Berden et al. (2014) hypothesize that the effect of voice and accountability and political stability in an importer country have an expected negative effect on aggregate exports, whereas we hypothesize that these effects mainly depend on the type of products traded.

The gravity model has been widely used to analyse the impact of various factors on trade such as the effect of trade facilitation measures, regional trade agreements and development aid etc. (Márquez-Ramos et al., 2012; Martínez-Zarzoso et al., 2009; Martínez-Zarzoso et al., 2016). In its basic form, this model assumes that trade between countries is directly related to a country's size and inversely related to the distance between them. Exports from country $\mathrm{i}$ to country $\mathrm{j}, \mathrm{X}_{\mathrm{ij}}$, are explained by their economic sizes (Gross Domestic Products, or GDPs), direct geographical distances and a set of dummies incorporating some common characteristics to specific flows such as common language, common border or colonial relationships. The specification of the gravity model of trade in its original multiplicative form for a single year is given by:

$$
X_{i j}=\beta_{0} G D P_{i}^{\beta_{1}} G D P_{j}^{\beta_{2}} D I S T_{i j}^{\beta_{3}} A_{i j}^{\beta_{4}} u_{i j}
$$

where $\operatorname{GDP}_{\mathrm{i}}\left(\mathrm{GDP}_{\mathrm{j}}\right)$ indicates the GDP of an exporter (importer), DIST $\mathrm{T}_{\mathrm{ij}}$ measures the distance between the two countries' capitals (or economic centres). A high level of income in the exporting country indicates a high level of production, which increases 
the availability of goods for exports. Therefore, $\beta_{1}$ is expected to be positive. The coefficient of $\mathrm{Y}_{\mathrm{j}}, \beta_{2}$, is also expected to be positive since a high level of income in the importing country suggests higher imports. The distance coefficient is expected to be negative since it is a proxy of all possible trade cost sources. $A_{i j}$ represents any other factors aiding or preventing trade between pairs of countries and $\mathrm{u}_{\mathrm{ij}}$ is the error term. Usually, $\mathrm{A}_{\mathrm{ij}}$ includes dummy variables for trading partners sharing a common language, colonial ties and common border, as well as trading bloc dummy variables that evaluate the effects of preferential trade agreements. The coefficients of all these bilateral variables are expected to be positive.

When the gravity model of trade is estimated using panel data, the time dimension is incorporated into the model and there are a number of econometric issues that have to be taken into account in order to obtain unbiased estimates of the model parameters.

For estimation purposes, equation (1), in log-linear form augmented with governance indicators and with the time dimension added becomes:

$\ln X_{i j t}=\beta_{0}+\beta_{1} \ln G D P_{i t}+\beta_{2} \ln G D P_{j t}+\beta_{3}\left(\ln D I S T_{i j}\right)+\beta_{4}\left(\operatorname{CONTIG}_{i j}\right)+$ $\beta_{5}\left(\right.$ COMLANG $\left._{i j}\right)+\beta_{6}\left(\operatorname{COLONY}_{i j}\right)+\beta_{7} \mathrm{RTA}_{\mathrm{ijt}}+\beta_{8} \mathrm{WTO}_{i j t}+\beta_{9} V A_{i t}+\beta_{10} P S_{i t}+$ $\beta_{11} G E_{i t}+\beta_{12} R Q_{i t}+\beta_{13} R L_{i t}+\beta_{14} C C_{i t}+\beta_{15} V A_{j t}+\beta_{16} P S_{j t}+\beta_{17} G E_{j t}+$ $\beta_{18} R Q_{j t}+\beta_{19} R L_{j t}+\beta_{20} C C_{j t}+\delta_{t}+\varepsilon_{i j t}$

where the variables $\operatorname{lnGDP}_{\mathrm{it}}$ and $\operatorname{lnGDP}_{\mathrm{jt}}$ are defined above; $\mathrm{DIST}_{\mathrm{ij}}$ is the bilateral distance between the economic centres of $\mathrm{i}$ and $\mathrm{j}$; as previously defined, CONTIG $\mathrm{ij}_{\mathrm{j}}$ is a dummy variable assuming a value of 1 if the two countries share a common land border (and 0 otherwise); COMLANG $\mathrm{ij}_{\mathrm{ij}}$ is a dummy variable that takes a value of 1 if the two countries share a common language; $\operatorname{COLONY}_{\mathrm{ij}}$ is a dummy variable that takes the value of 1 when countries $\mathrm{i}$ and $\mathrm{j}$ have ever had a colonial relationship, and 0 
otherwise; $\mathrm{RTA}_{\mathrm{ijt}}$ is a variable that takes the value of 1 if countries $\mathrm{i}$ and $\mathrm{j}$ belong to the same regional integration agreement; $\mathrm{WTO}_{\mathrm{ijt}}$ is a variable that takes the value of 1 if countries $\mathrm{i}$ and $\mathrm{j}$ belong to the World Trade Organization in year t. The rest of the variables are the six individual measures included in the "Worldwide Governance Indicators" from the World Bank: Voice and Accountability (VA), Political Stability (PS), Government Effectiveness (GE), Regulatory Quality (RQ), Rule of Law (RL) and Control of Corruption (CC). Each governance variable is specified in model (2) with the subscripts it or $j t$ denoting that they vary by exporter-and-time or importer-and-time.

According to Anderson and van Wincoop (2003), Feenstra (2004) and Baier and Bergstrand (2007) among others, the traditional gravity model as specified in (2) is atheoretical because it does not account for the theoretically-motivated multilateral resistance terms (MRT), which refer to exporter and importer price indices with respect to all trading partners and represent the general equilibrium effects that imply that trade between any given pair of countries also depends on the prices in the rest of the potential trading partners of the given pair of countries. Some authors estimate equation (2) by adding bilateral or country-pair ("pair") dummy variables, to account for MRT. In this case, the coefficients of the bilateral variables that are in specification (2) cannot be directly estimated. ${ }^{2}$ The model becomes:

\footnotetext{
${ }^{2}$ One line of research using a gravity model of trade deals with the difficulty of obtaining unbiased coefficients for the effect of regional integration on trade flows (Baier and Bergstrand, 2007; Baier et al., 2014). If regional integration variables correlate with the error term of the gravity equation, there is an omitted variable bias due to the (unknown) MRT (Anderson and van Wincoop, 2003). Baier and Bergstrand (2007) refer to an endogeneity problem that is difficult to solve by using instrumental variables, given the difficulty of finding instruments that are correlated with bilateral trade but not with RTA dummy variables. For this reason, they propose using pair dummy variables to mitigate endogeneity. Similarly, an endogeneity problem might arise when the target variable is institutional quality, using fixed effects is a way to deal with omitted variable biases.
} 


$$
\begin{aligned}
& \ln X_{i j t}=\beta_{0}+\beta_{1} \ln G D P_{i t}+\beta_{2} \ln G D P_{j t}+\beta_{3} \mathrm{RTA}_{\mathrm{ijt}}+\beta_{4} \mathrm{WTO}_{i j t}+\beta_{5} V A_{i t}+\beta_{6} P S_{i t}+ \\
& \beta_{7} G E_{i t}+\beta_{8} R Q_{i t}+\beta_{9} R L_{i t}+\beta_{10} C C_{i t}+\beta_{11} V A_{j t}+\beta_{12} P S_{j t}+\beta_{13} G E_{j t}+\beta_{14} R Q_{j t}+ \\
& \beta_{15} R L_{j t}+\beta_{16} C C_{j t}+\gamma_{i j}+\delta_{t}+\varepsilon_{i j t}
\end{aligned}
$$

where $\gamma_{i j}$ is a country-pair fixed effect that captures all time-invariant bilateral factors influencing trade flows, which absorb all effects that are country-pair specific, namely distance, common border, language and colonial links. Thus, these country-pair-specific variables do not appear in equation (3). However, a number of authors (e.g. Baier and Bergstrand, 2007) claim that in a panel-data setting, multilateral resistance is timevarying because the factors that affect international prices change over time and recommend adding time-variant MRT to the gravity model. We could think of adding origin-and-time and destination-and-time dummy variables that vary every 5 years and account for MRT (as in Gylfason et al, 2015). The main reason for this choice is that the governance indicators vary by country and year and in order to account for their effects on trade we would like to retain its short-run variability, while controlling for other factors that are more persistent such as tastes, cultural factors and business cycles.

A widely used model specification that accounts for the so-called MRT and also for unobserved heterogeneity that is attached to each bilateral trade flow, consists of extending specification (2) with origin-and-time and destination-and-time and with pairspecific dummy variables:

$$
\begin{aligned}
& \ln X_{i j t}=\beta_{0}+\beta_{1} \ln G D P_{i t}+\beta_{2} \ln G D P_{j t}+\beta_{3} \mathrm{RTA}_{\mathrm{ijt}}+\beta_{4} \mathrm{WTO}_{i j t}+\beta_{5} V A_{i t}+\beta_{6} P S_{i t}+ \\
& \beta_{7} G E_{i t}+\beta_{8} R Q_{i t}+\beta_{9} R L_{i t}+\beta_{10} C C_{i t}+\beta_{11} V A_{j t}+\beta_{12} P S_{j t}+\beta_{13} G E_{j t}+\beta_{14} R Q_{j t}+ \\
& \beta_{15} R L_{j t}+\beta_{16} C C_{j t}+\gamma_{i j}+\pi_{i, t 5}+\tau_{j, t 5}+\delta_{t}+\varepsilon_{i j t}
\end{aligned}
$$

where the gravity and governance variables and $\gamma_{i j}$ have been defined above. $\pi_{i, t 5}$ and $\tau_{j, t 5}$ denote origin-and-time and destination-and-time dummy variables that vary every 5 years and account for MRT. 
Next, in the following model we add the governance variables as the sum of the indicators for an exporter and an importer. In this sense, we will account for the joint influence of the levels of governance in the exporter and importer countries on exports. The estimation model is given by:

$\ln X_{i j t}=\beta_{0}+\beta_{1} \ln G D P_{i t}+\beta_{2} \ln G D P_{j t}+\beta_{3} \mathrm{RTA}_{\mathrm{ijt}}+\beta_{4} \mathrm{WTO}_{i j t}+\beta_{5} V A_{i j t}+\beta_{6} P S_{i j t}+$ $\beta_{7} G E_{i j t}+\beta_{8} R Q_{i j t}+\beta_{9} R L_{i j t}+\beta_{10} C C_{i j t}+\gamma_{i j}+\pi_{i, t 5}+\tau_{j, t 5}+\varepsilon_{i j t}$

where the gravity variables, $\gamma_{i j}$ and $\pi_{i, t 5}$ and $\tau_{j, t 5}$ have been defined above. The righthand-side (RHS) variables of interest now have exporter-importer-time variability, and are computed as the sum of each corresponding WGI for an exporter and an importer in year t. This will also help to avoid collinearity issues with the MRT. The main drawback of this specification is that we will not be able to obtain a separate effect for exporters and importers.

Finally, we consider similarity measures of governance between the origin and the destination of trade flows. Hence, we investigate whether a similarity in governance indicators makes a difference. To do so, we use a simple method to construct indicators of similarity relying on "fuzzy metrics". Fuzzy metrics allow us to model the concept of similarity across origins and destinations. Therefore, in the spirit of Alamá-Sabater et al. (2016), we apply the following equation to construct fuzzy variables of the WGIs indicators:

$$
f u z z y W G I_{i j t}=\frac{\min \left(W G I_{i t}, W G I_{j t}\right)+1}{\max \left(W G I_{i t}, W G I_{j t}\right)+1}
$$

where WGI denotes the corresponding WGI indicator. Fuzzy-WGI lies between 0 and 1 and is maximized if both $i$ and $j$ countries have the same level of governance in year $t$. For diverging levels of governance between the two countries, the indicator approaches zero. Then we augment specification (5) with these similarity measures for each of the six WGI considered. The corresponding gravity model is given by: 


$$
\begin{aligned}
& \ln X_{i j t}=\beta_{0}+\beta_{1} \ln G D P_{i t}+\beta_{2} \ln G D P_{j t}+\beta_{3} \mathrm{RTA}_{\mathrm{ijt}}+\beta_{4} \mathrm{WTO}_{i j t}+\beta_{5} V A_{i j t}+\beta_{6} P S_{i j t}+ \\
& \beta_{7} G E_{i j t}+\beta_{8} R Q_{i j t}+\beta_{9} R L_{i j t}+\beta_{10} C C_{i j t}+\beta_{11} f u z z y V A_{i j t}+\beta_{12} f u z z y P S_{i j t}+ \\
& \beta_{13} f u z z y G E_{i j t}+\beta_{14} f u z z y R Q_{i j t}+\beta_{15} f u z z y R L_{i j t}+\beta_{16} f u z z y C C_{i j t}+\gamma_{i j}+\pi_{i, t 5}+ \\
& \tau_{j, t 5}+\varepsilon_{i j t}
\end{aligned}
$$

where fuzzy denotes that the corresponding WGI variable has been transformed according to equation (6).

\section{Data and Variables}

The sample of exporting countries considered in this research is composed of 19 MENA countries, ${ }^{3}$ as defined by the World Bank. As partners, we consider 189 countries (see Table A.1 in Appendix 1) and the period under study runs from 1996 to 2013.

Table 1 presents the descriptive statistics for the variables included in the analysis and indicates the expected signs of the estimated coefficients for each of the RHS variables. The figures show that exporter countries, i.e. MENA, present lower values, on average, than the sample of importers in two out of the three concepts distinguished by Berden, et al. (2014): 1) the process by which governments are selected, monitored and replaced and 2) the capacity of the government to effectively formulate and implement sound policies and 3) the respect of citizens and the state of institutions that govern economic and social interactions.

According to Table 1 , it is in the category voice and accountability where MENA countries (i.e. exporters) seem to have the greatest drawback in WGIs: while the average in the sample of MENA countries (as exporters) in this indicator equals 29.56,

\footnotetext{
${ }^{3}$ The MENA countries are: Algeria, Bahrain, Djibouti, Egypt, Iran, Iraq, Jordan, Kuwait, Lebanon, Libya, Morocco, Oman, Qatar, Saudi Arabia, Sudan, Syria, Tunisia, United Arab Emirates, Yemen. For comparative purposes, we also estimate the models for all trade flows among the 189 countries.
} 
it equals 55.05 for the sample of 189 importers. Additionally, the maximum value of this indicator for MENA countries is 52.45, this (0-100) standardized value is much lower than the rest of the governance indicators in the region over this time period.

The WGIs first constructed by Kaufmann et al. (2007) for the World Bank are normalized onto a 0-100 scale (as in Berden el al, 2014). The six aggregate indicators are based on 31 underlying data sources reporting the perceptions of governance of a large number of survey respondents and expert assessments worldwide. Details on the underlying data sources, the aggregation method and the interpretation of the indicators can be found in Kaufmann et al. (2010). Each of these indicators represents a different dimension of governance and are defined as follows:

Voice and accountability measures the extent to which a country's citizens are able to participate in selecting their government, as well as the freedom of expression of association and the media. Of the six WGIs, this variable best captures most individuals' notion of how a democratic institution that fosters voice and accountability affects pluralism.

Political stability measures perceptions of the likelihood that the government will not be destabilised or overthrown by unconstitutional or violent means.

Government effectiveness measures the quality of public services, the civil service (and its degree of independence), the policy formation and implementation process and the government's overall commitment to implementing policies.

Regulatory quality indicates the ability of the government to formulate and implement sound policies and regulations that permit and promote private sector development.

Rule of law measures the extent to which agents have confidence in and abide by the rules of society, and with particular emphasis, the quality of contract enforcement, the police and the courts. 
Control of corruption measures the extent to which public power is not exercised for private gain, including both petty and grand forms of corruption as well as the extent of 'capture' by elites and private interests.

Berden et al. (2014) grouped the above-described indicators into three different concepts. The first deals with the "process by which governments are selected, monitored and replaced" and it is measured by two indicators: 1) the voice and accountability of a country's citizens and 2) political stability. According to these authors, holding constant the influences of other measures of governance, the coefficients for importers associated with this concept are expected to be negative. ${ }^{4}$ The second category of the WGIs refers to factors influencing the "capacity of the government to effectively formulate and implement sound policies"; the two WGIs associated with this category are 3) the government effectiveness and 4) regulatory quality. Both are expected to be positively associated with trade flows. Finally, the third category refers to factors associated with "respect of citizens and the state for institutions that govern economic and social interactions"; the two WGIs in this category are 5) rule of law and 6) the control of corruption. Both are also expected to be positively associated with trade flows. On the consequences of the MENA region's governance indicators in terms of exports, institutions can either directly affect the willingness of agents to trade abroad or affect economic variables that may in turn lower the propensity of agents to trade (Méon and Sekkat, 2004). On the one hand, an improvement of the governance indicators in MENA countries may lead to higher exports arising from the MENA region due to a better business environment that could facilitate doing business abroad. On the other hand, an improvement in the governance

\footnotetext{
${ }^{4}$ In particular, they argue that greater pluralism in an importing country is likely to increase resistance to international trade as larger host country pluralism is like a tax, equivalent to an ad-valorem tariff. Additionally, it is possible that political stability could increase both the probability of and level of FDI. Consequently, if political stability lowers the cost of FDI, and FDI and trade are substitutes in relation to relative investment and trade costs, political stability could have a negative effect on trade.
} 
indicators might affect comparative and competitive advantages, as well as existing trade relationships, having an ambiguous effect on exports arising from MENA countries. Therefore, it is an empirical question whether improved governance indicators in the region lead to higher exports from MENA countries. 


\section{Table 1. Descriptive statistics}

\begin{tabular}{|c|c|c|c|c|c|c|c|}
\hline Variable & Description & Expected sign & Obs & Mean & Std. Dev. & Min & Max \\
\hline $\ln X$ & Natural log of the export flows between the two countries & & 29296 & 14.34 & 3.47 & 0.00 & 24.87 \\
\hline lnGDP_it & Natural log of an exporter's GDP & + & 61992 & 24.40 & 1.43 & 20.02 & 27.34 \\
\hline $\operatorname{lnGDP} \_j t$ & Natural log of an importer's GDP & + & 61655 & 23.52 & 2.48 & 16.33 & 30.45 \\
\hline lnPCGDP_it & Natural log of an exporter's GDP per capita in current US\$ & $+/-$ & 61992 & 8.45 & 1.34 & 5.68 & 11.45 \\
\hline $\operatorname{lnPCGDP}$ jt & Natural log of an importer's GDP per capita in current US\$ & $+/-$ & 61655 & 8.08 & 1.60 & 4.28 & 11.54 \\
\hline \multicolumn{8}{|c|}{ Process by which governments are selected, monitored and replaced } \\
\hline VAstd_it & Exporter's standardised value (0-100) of Voice and Accountability & $+/-$ & 55083 & 29.56 & 11.85 & 2.54 & 52.45 \\
\hline PSstd_it & Exporter's standardised value (0-100) of Political Stability & $+/-$ & 51386 & 51.58 & 22.78 & 0.00 & 93.63 \\
\hline \multicolumn{8}{|c|}{ Capacity of the government to effectively formulate and implement sound policies } \\
\hline GEstd_it & Exporter's standardised value (0-100) of Government Effectiveness & $+/-$ & 55083 & 43.23 & 15.49 & 3.83 & 77.45 \\
\hline RQstd_it & Exporter's standardised value (0-100) of Regulatory Quality & $+/-$ & 55083 & 46.99 & 17.18 & 3.40 & 79.79 \\
\hline \multicolumn{8}{|c|}{ Respect of citizens and the state for institutions that govern economic and social interactions } \\
\hline RLstd_it & Exporter's standardised value (0-100) of Rule of Law & $+/-$ & 55083 & 47.82 & 17.14 & 9.98 & 79.16 \\
\hline CCstd_it & Exporter's standardised value (0-100) of Control of Corruption & $+/-$ & 55083 & 34.98 & 17.02 & 1.97 & 81.22 \\
\hline \multicolumn{8}{|c|}{ Process by which governments are selected, monitored and replaced } \\
\hline VAstd_jt & Importer's standardised value $(0-100)$ of Voice and Accountability & $+/-$ & 53246 & 55.05 & 26.07 & 0.00 & 100.00 \\
\hline PSstd_jt & Importer's standardised value (0-100) of Political Stability & $+/-$ & 49170 & 62.06 & 22.24 & 0.00 & 100.00 \\
\hline \multicolumn{8}{|c|}{ Capacity of the government to effectively formulate and implement sound policies } \\
\hline GEstd_jt & Importer's standardised value (0-100) of Government Effectiveness & + & 52562 & 49.01 & 22.24 & 0.00 & 100.00 \\
\hline RQstd_jt & Importer's standardised value (0-100) of Regulatory Quality & + & 52581 & 54.44 & 22.23 & 0.00 & 100.00 \\
\hline \multicolumn{8}{|c|}{ Respect of citizens and the state for institutions that govern economic and social interactions } \\
\hline RLstd_jt & Importer's standardised value $(0-100)$ of Rule of Law & + & 53246 & 53.05 & 23.09 & 0.00 & 100.00 \\
\hline CCstd_jt & Importer's standardised value (0-100) of Control of Corruption & + & 52562 & 40.92 & 23.78 & 0.00 & 100.00 \\
\hline
\end{tabular}

Note: Additional "gravity" variables included in the regressions, namely, RTA, WTO, DIST, CONTIG, COMLANG and COLONY are described in pages 10-11. 


\section{Estimation Results}

\subsection{Main results}

Table 2 shows the results obtained from estimating specifications (2) and (3) of the gravity model of trade. The RHS variables of interest are the WGI variables for the exporting and importing countries. Columns 1-2 present results for all (189) countries obtained from estimating the traditional gravity model with time effects (Equation 2) and the model adding bilateral fixed effects (Equation 3), while columns 3 and 4 present estimations of the same two specifications for MENA exporters. ${ }^{5}$

The first column of Table 2 shows that an increase in both an exporter's GDP and an importer's GDP, increases trade flows and the coefficients are close to the unitary theoretically-expected magnitude; distance has the expected negative and significant effect on exports, while common language, common border and colonial links positively affect exports. Also, the RTA and WTO membership dummies present the expected positive effect on exports. The results concerning these gravity variables differ when the sample of exporters is restricted to MENA countries, as shown in column (3) of Table 2. Income elasticities of MENA exporters are considerably lower than the elasticity of the average exporter and common border is not statistically significant, reflecting the fact that MENA countries do not trade more with neighbouring countries than with others. Concerning the common language effect, it is considerably higher than for the whole sample, whereas a colonial relationship shows a lower effect for MENA exporters.

With regards to WGI variables in the traditional gravity model specification estimated for all trading partners, the coefficients obtained in column (1) are all positive and significant for both exporter and importer countries; however, we claim that these

\footnotetext{
${ }^{5}$ A model with interactions between a MENA dummy variable and the target variables provides similar outcomes. A separate estimation for MENA countries is preferred given that elasticities for other variables also differ between MENA and the average exporter.
} 
estimates are biased due to the exclusion of MRT in the model. The same bias affects the estimates in column (3) for MENA exporters. In this column, the coefficients for the importers' WGI indicators are all negative and significant, which is unexpected. ${ }^{6}$ Results in column (2) of Table 2 show that after controlling for bilateral time-invariant heterogeneity (equation 3) the results differ from column (1) concerning voice and accountability and political stability, the former is not significant for the exporter and the latter is negative and significant for the exporter and not statistically significant for the importer.

Table 2. Gravity model estimates for governance indicators

\begin{tabular}{|c|c|c|c|c|}
\hline \multicolumn{2}{|l|}{ Dep.Var: } & & \multicolumn{2}{|c|}{ MENA exporters } \\
\hline Single WGI & (1) & $(2)$ & (3) & (4) \\
\hline VARIABLES & Baseline & Pair-FE & Baseline & Pair-FE \\
\hline \multirow[t]{2}{*}{ InGDP_it } & $1.254 * * *$ & $0.561 * * *$ & $0.873 * * *$ & $0.169 *$ \\
\hline & {$[0.00675]$} & {$[0.0256]$} & {$[0.0453]$} & [0.0919] \\
\hline \multirow[t]{2}{*}{ InGDP_jt } & $0.849 * * *$ & $0.688 * * *$ & $0.926 * * *$ & $0.548 * * *$ \\
\hline & {$[0.00624]$} & [0.0199] & {$[0.0231]$} & [0.0678] \\
\hline \multirow[t]{2}{*}{ InDIST_ij } & $-1.205^{* * *}$ & & $-1.219 * * *$ & \\
\hline & [0.0191] & & {$[0.0628]$} & \\
\hline \multirow[t]{2}{*}{ CONTIG_ij } & $1.102 * * *$ & & 0.165 & \\
\hline & [0.0908] & & {$[0.284]$} & \\
\hline \multirow[t]{2}{*}{ COMLANG_ij } & $0.735^{* * *}$ & & $1.384 * * *$ & \\
\hline & [0.0395] & & [0.133] & \\
\hline \multirow[t]{2}{*}{ COLONY_ij } & $0.806 * * *$ & & $0.562 * * *$ & \\
\hline & {$[0.0563]$} & & [0.131] & \\
\hline \multirow[t]{2}{*}{ RTA } & $0.770 * * *$ & $0.0508^{* *}$ & $0.283^{* *}$ & 0.107 \\
\hline & [0.0381] & [0.0227] & [0.117] & {$[0.0800]$} \\
\hline \multirow[t]{2}{*}{ WTO } & $0.248 * * *$ & $0.217 * * *$ & $0.665^{* * *}$ & $0.214^{* *}$ \\
\hline & [0.0309] & {$[0.0252]$} & [0.0883] & [0.0879] \\
\hline \multirow[t]{2}{*}{ VAstd_it } & $0.00331 * * *$ & -0.00120 & 0.00286 & $-0.00751 * *$ \\
\hline & [0.000593] & [0.00104] & {$[0.00415]$} & {$[0.00330]$} \\
\hline \multirow[t]{2}{*}{ PSstd_it } & $0.00779 * * *$ & $-0.00121 *$ & $0.0171 * * *$ & 0.00302 \\
\hline & [0.000639] & [0.000692] & {$[0.00251]$} & {$[0.00285]$} \\
\hline \multirow[t]{2}{*}{ GEstd_it } & $0.00856 * * *$ & $0.0111 * * *$ & $0.0271 * * *$ & $0.0166 * * *$ \\
\hline & [0.000730] & [0.00115] & {$[0.00396]$} & [0.00528] \\
\hline RQstd_it & $0.00764 * * *$ & $0.00831 * * *$ & $0.0170 * * *$ & $0.0157 * * *$ \\
\hline
\end{tabular}

\footnotetext{
${ }^{6}$ The results in columns (1) and (3) are shown for comparative purposes and to also show the coefficients of the traditional gravity variables for MENA countries and for the whole sample.
} 


\begin{tabular}{|c|c|c|c|c|}
\hline & {$[0.000748]$} & [0.00113] & [0.00337] & {$[0.00406]$} \\
\hline \multirow[t]{2}{*}{ RLstd_it } & $0.00601 * * *$ & $0.00445^{* * *}$ & $0.0158^{* * *}$ & $-0.0195 * * *$ \\
\hline & [0.000648] & {$[0.00130]$} & [0.00369] & [0.00433] \\
\hline \multirow[t]{2}{*}{ CCstd_it } & $0.00442 * * *$ & $0.00489 * * *$ & $0.00850 * * *$ & $0.0209 * * *$ \\
\hline & {$[0.000584]$} & [0.000909] & {$[0.00325]$} & {$[0.00268]$} \\
\hline \multirow[t]{2}{*}{ VAstd_jt } & $0.00496 * * *$ & $0.00485^{* * *}$ & $-0.00885^{* * *}$ & $0.00939 * * *$ \\
\hline & {$[0.000560]$} & {$[0.000871]$} & [0.00193] & [0.00289] \\
\hline \multirow[t]{2}{*}{ PSstd_jt } & $0.00357^{* * *}$ & 0.000195 & $-0.00876 * * *$ & $0.00402 *$ \\
\hline & {$[0.000605]$} & {$[0.000607]$} & [0.00198] & [0.00208] \\
\hline \multirow[t]{2}{*}{ GEstd_jt } & $0.00551 * * *$ & $0.00426^{* * *}$ & $-0.00703 * * *$ & 0.00596 \\
\hline & {$[0.000713]$} & [0.00103] & {$[0.00247]$} & [0.00379] \\
\hline \multirow[t]{2}{*}{ RQstd_jt } & $0.00528 * * *$ & $0.00456 * * *$ & $-0.0105^{* * *}$ & 0.000608 \\
\hline & [0.000729] & [0.000943] & {$[0.00251]$} & [0.00337] \\
\hline \multirow[t]{2}{*}{ RLstd_jt } & $0.00513 * * *$ & $0.00493 * * *$ & $-0.00424 *$ & $0.00958 * *$ \\
\hline & {$[0.000637]$} & [0.00109] & {$[0.00220]$} & [0.00394] \\
\hline \multirow[t]{2}{*}{ CCstd_jt } & $0.00434 * * *$ & $0.00346 * * *$ & $-0.00579 * * *$ & $0.00520 *$ \\
\hline & [0.000597] & [0.000834] & [0.00209] & [0.00285] \\
\hline Time FE & yes & yes & yes & yes \\
\hline Observations & 245,375 & 245,375 & 23,672 & 23,672 \\
\hline R-squared & 0.65 & 0.163 & 0.477 & 0.195 \\
\hline
\end{tabular}

Note: Robust standard errors in brackets. ${ }^{* * *} p<0.01,{ }^{* *} p<0.05,{ }^{*} p<0.1$. WGI included independently in the model. Governance indicators: VA: Voice and Accountability; PS: Political Stability; GE: Government Effectiveness; RQ: Regulatory Quality; RL: Rule of Law and CC: Control of Corruption; std indicate standardized values (0-100).

When the sample is restricted to MENA exporters, the main difference is that voice and accountability and rule of law in exporter countries, show a negative and significant effect on exports (column 4). For importers, the coefficients associated with voice and accountability, political stability, rule of law and control of corruption are positive and statistically significant.

We now turn to the estimation of an additional specification, while restricting the sample to MENA countries to run additional regressions. Only results related to governance indicators are presented in the main text, full results are presented in Appendix B.

Table 3 shows the results when the gravity model is estimated adding exporter-and-time and importer-and-time dummy variables that vary every 5 years (Equation 4). The results for all countries (in column 1) indicate that higher levels of political stability, rule of law and the control of corruption in the exporting countries are associated with 
higher exports. Higher values of voice and accountability, government effectiveness, regulatory quality, rule of law and the control of corruption in importing countries are also positively associated with exports.

\section{Table 3. Results for all countries and for MENA}

\begin{tabular}{|c|c|c|c|}
\hline $\begin{array}{l}\text { Dep.Var: In Xijt } \\
\text { Ind. Variables: Single WGI }\end{array}$ & $\begin{array}{c}\text { All countries } \\
(1)\end{array}$ & $\begin{array}{c}\text { MENA } \\
(2) \\
\end{array}$ & $\begin{array}{c}\text { Intra-MENA } \\
(3)\end{array}$ \\
\hline VAstd_it & $\begin{array}{c}-0.00180 \\
{[0.00140]}\end{array}$ & $\begin{array}{c}0.0142 * * * \\
{[0.00469]}\end{array}$ & $\begin{array}{c}0.00762 \\
{[0.00857]}\end{array}$ \\
\hline PSstd_it & $\begin{array}{c}0.00208 * * * \\
{[0.000778]}\end{array}$ & $\begin{array}{c}0.00944 * * * \\
{[0.00256]}\end{array}$ & $\begin{array}{l}0.000246 \\
{[0.00534]}\end{array}$ \\
\hline GEstd_it & $\begin{array}{r}-0.000514 \\
{[0.00138]}\end{array}$ & $\begin{array}{c}0.0179 * * * \\
{[0.00578]}\end{array}$ & $\begin{array}{c}0.0253 * * \\
{[0.0108]}\end{array}$ \\
\hline RQstd_it & $\begin{array}{c}0.00107 \\
{[0.00123]}\end{array}$ & $\begin{array}{l}0.000193 \\
{[0.00431]}\end{array}$ & $\begin{array}{c}0.00679 \\
{[0.00837]}\end{array}$ \\
\hline RLstd_it & $\begin{array}{c}0.00446 * * * \\
{[0.00158]}\end{array}$ & $\begin{array}{l}0.0185 * * * \\
{[0.00501]}\end{array}$ & $\begin{array}{l}0.0396 * * * \\
{[0.00950]}\end{array}$ \\
\hline CCstd_it & $\begin{array}{c}0.00311 * * * \\
{[0.00102]}\end{array}$ & $\begin{array}{l}0.0218 * * * \\
{[0.00312]} \\
\end{array}$ & $\begin{array}{l}0.0224 * * * \\
{[0.00570]} \\
\end{array}$ \\
\hline VAstd_jt & $\begin{array}{c}0.00339 * * * \\
{[0.00108]}\end{array}$ & $\begin{array}{l}-0.00021 \\
{[0.00405]}\end{array}$ & $\begin{array}{c}0.0118 \\
{[0.00728]}\end{array}$ \\
\hline PSstd_jt & $\begin{array}{c}0.000923 \\
{[0.000698]}\end{array}$ & $\begin{array}{c}-0.0019 \\
{[0.00259]}\end{array}$ & $\begin{array}{c}-0.00292 \\
{[0.00488]}\end{array}$ \\
\hline GEstd_jt & $\begin{array}{c}0.00257^{* *} \\
{[0.00118]}\end{array}$ & $\begin{array}{c}0.00339 \\
{[0.00495]}\end{array}$ & $\begin{array}{c}0.00165 \\
{[0.00888]}\end{array}$ \\
\hline RQstd_jt & $\begin{array}{c}0.00249 * * \\
{[0.00107]}\end{array}$ & $\begin{array}{l}0.000137 \\
{[0.00418]}\end{array}$ & $\begin{array}{c}-0.01 \\
{[0.00687]}\end{array}$ \\
\hline RLstd_jt & $\begin{array}{c}0.00422 * * * \\
{[0.00129]}\end{array}$ & $\begin{array}{c}-0.00181 \\
{[0.00510]}\end{array}$ & $\begin{array}{l}-0.0180 * * \\
{[0.00841]}\end{array}$ \\
\hline CCstd_jt & $\begin{array}{c}0.00178 * \\
{[0.000950]}\end{array}$ & $\begin{array}{c}0.00131 \\
{[0.00357]}\end{array}$ & $\begin{array}{c}0.00204 \\
{[0.00559]} \\
\end{array}$ \\
\hline
\end{tabular}

Note: Full results are presented in Appendix B. Robust standard errors in brackets. *** $\mathrm{p}<0.01$, ** $\mathrm{p}<0.05, * \mathrm{p}<0.1$. WGI included independently in the model. Governance indicators: VA: Voice and Accountability; PS: Political Stability; GE: Government Effectiveness; RQ: Regulatory Quality; RL: Rule of Law and CC: Control of Corruption; std indicate standardized values (0-100). Exporter and time and importer and time FE and pair FE included. Full results are presented in in the Appendix in Tables B.1 (for all countries); B.2 (MENA exporters) and B.3 (intra-MENA trade).

When the sample is restricted to MENA exporters (column 2 in Table 3), it seems surprising that the significance found for the WGIs in importing countries vanishes, whereas voice and accountability, political stability, government effectiveness, rule of law and the control of corruption in MENA exporters are associated with higher exports and the corresponding coefficients are higher than for the sample with all exporters. For instance, an increase in the index of voice and accountability of 10 points is associated 
with an increase in exports of 0.14 percent. Considering that the average for this item in MENA countries is 29 , doubling the index would increase MENA exports by around 0.5 percent.

When the model is estimated including only intra-MENA trade flows (column 2 in Table 3, full results in Table B.3), only government effectiveness, rule of law and the control of corruption in exporter countries are positively associated with exports, whereas MENA countries export more to MENA importers with lower scores in rule of law.

Table 4 shows the outcomes of regressing export flows on the sum of the exporter (i) and importer (j) governance indicators. In column (1) results are shown for all exporters and in column (3) for MENA exporters, respectively. Results show that whereas higher levels of voice and accountability are associated with lower exports, the higher the indicators of political stability, government effectiveness, regulatory quality and rule of law in (the pair of) trading partners, the higher the trade flows among them. The results are similar for MENA exporters with the only exception of regulatory quality that is not statistically significant, whereas the control of corruption becomes statistically significant and is positively related to MENA exports.

Finally, we turn to the importance of analysing the role of similarity in governance indicators across countries. As stated by Horsewood and Voicu (2012): “A nation's business culture could be a deterrent to international trade and it may be that similarities of ethical standards between countries are an important issue. An international transaction will take place if both the buyer and seller believe the side payment to a government official or a personal kickback, is perfectly acceptable. Alternatively, if either party comes from a country where backhanders are not the norm, then there is a cultural barrier preventing the exchange of goods and services" (page 5). Therefore, we 
take the similarity of governance across exporters and importers into account, since it could be that the difference between governance indicators in these two types of economies (exporter $\mathrm{i}$ and importer $\mathrm{j}$ ) discourages bilateral trade between them.

Table 4. Gravity model with time-variant MTR and pair FE. Adding fuzzy similarity measures

\begin{tabular}{|c|c|c|c|c|}
\hline \multirow[t]{2}{*}{ Dep.Var: In Xijt } & \multicolumn{2}{|l|}{ All countries } & \multicolumn{2}{|c|}{ MENA exporters } \\
\hline & $(1)$ & (2) & (3) & (4) \\
\hline Ind. Variables & Govij & Govij,i-j & Govij & Govij,i-j \\
\hline \multirow[t]{2}{*}{ RTA } & $0.104 * * *$ & $0.102 * * *$ & $0.282 * * *$ & $0.282 * * *$ \\
\hline & {$[0.0225]$} & {$[0.0225]$} & {$[0.0749]$} & [0.0749] \\
\hline \multirow[t]{2}{*}{ WTO } & $0.212 * * *$ & $0.212 * * *$ & $0.268 * * *$ & $0.268 * * *$ \\
\hline & [0.0289] & {$[0.0289]$} & {$[0.0920]$} & [0.0920] \\
\hline \multirow[t]{2}{*}{ VAstd_ijt } & $-0.00897 * * *$ & $-0.00993 * * *$ & $-0.00802 * * *$ & $-0.00786 * *$ \\
\hline & [0.000794] & {$[0.000848]$} & {$[0.00300]$} & [0.00309] \\
\hline \multirow[t]{2}{*}{ PSstd_ijt } & $0.00714 * * *$ & $0.00307 * * *$ & $0.0107 * * *$ & 0.00182 \\
\hline & [0.000473] & [0.000777] & [0.00153] & [0.00279] \\
\hline \multirow[t]{2}{*}{ GEstd_ijt } & $0.00153^{*}$ & $0.00558 * * *$ & $0.00660 *$ & $0.0129 * *$ \\
\hline & [0.000840] & {$[0.00129]$} & {$[0.00363]$} & {$[0.00518]$} \\
\hline \multirow[t]{2}{*}{ RQstd_ijt } & $0.00491 * * *$ & $0.00501 * * *$ & 0.00203 & 0.00649 \\
\hline & [0.000718] & {$[0.00122]$} & [0.00253] & [0.00455] \\
\hline \multirow[t]{2}{*}{ RLstd_ijt } & $0.0181 * * *$ & $0.00588 * * *$ & $0.0235 * * *$ & 0.000531 \\
\hline & [0.000902] & {$[0.00143]$} & [0.00302] & [0.00566] \\
\hline \multirow[t]{2}{*}{ CCstd_ijt } & $4.04 \mathrm{E}-05$ & 0.00142 & $0.00900 * * *$ & 0.00474 \\
\hline & {$[0.000666]$} & {$[0.00100]$} & {$[0.00226]$} & [0.00356] \\
\hline \multirow[t]{2}{*}{ fuzzyVA_ijt } & & $0.202 * * *$ & & -0.0457 \\
\hline & & {$[0.0605]$} & & [0.171] \\
\hline \multirow[t]{2}{*}{ fuzzyPS_ijt } & & $0.124 * * *$ & & 0.163 \\
\hline & & {$[0.0476]$} & & [0.154] \\
\hline \multirow[t]{2}{*}{ fuzzyGE_ijt } & & 0.0878 & & 0.0343 \\
\hline & & {$[0.0692]$} & & [0.237] \\
\hline \multirow[t]{2}{*}{ fuzzyRQ_ijt } & & $0.311 * * *$ & & $0.557 * *$ \\
\hline & & [0.0688] & & {$[0.227]$} \\
\hline \multirow[t]{2}{*}{ fuzzyRL_ijt } & & $0.255^{* * *}$ & & $0.590 * *$ \\
\hline & & {$[0.0722]$} & & {$[0.239]$} \\
\hline \multirow[t]{2}{*}{ fuzzyCC_ijt } & & 0.0729 & & 0.219 \\
\hline & & [0.0459] & & [0.139] \\
\hline Bilateral FE & yes & yes & yes & yes \\
\hline MRT (i,5y,j5y) & yes & yes & yes & yes \\
\hline Observations & 252,429 & 252,429 & 24,619 & 24,619 \\
\hline R-squared & 0.204 & 0.204 & 0.249 & 0.249 \\
\hline Number of pairid & 24,787 & 24,787 & 2,804 & 2,804 \\
\hline
\end{tabular}

Note: Robust standard errors in brackets. ${ }^{* *} p<0.01,{ }^{* *} \mathrm{p}<0.05,{ }^{*} \mathrm{p}<0.1$. WGI included independently in the model. Governance indicators: VA: Voice and Accountability; PS: Political Stability; GE:

Government Effectiveness; RQ: Regulatory Quality; RL: Rule of Law and CC: Control of Corruption; std 
indicate standardized values (0-100). "fuzzy" prefix denotes the fuzzy similarity indicators for each governance item, constructed according to equation (6).

Columns (2) and (4) in Table 4 display the results of adding the fuzzy metrics for the WGIs for the whole sample and for the sample of MENA exporters, respectively. In this case, whereas four WGIs are statistically significant for the whole sample, namely similarities in voice and accountability, political stability, regulatory quality and rule of law, only two of them stay significant for MENA exporters: regulatory quality and rule of law. This outcome could be interpreted as indicating that more similarities in the capacity of the government to effectively formulate and implement sound policies between two trading countries is associated with higher trade flows between them.

\subsection{Robustness checks}

As a first robustness check, model (3) has been estimated using zero trade flows and controlling for heteroskedasticity by estimating the model using a Pseudo Poisson Maximum Likelihood (PPML) estimation technique with bilateral fixed effects as proposed by several authors (see Head and Mayer, 2014). The results are shown in Table A.2 in the Appendix ${ }^{7}$. The results concerning the WGI variables remain similar to those found in Table 2, column 2, with a comparable log-log specification.

As a second robustness check, the gravity model was estimated using intra-MENA trade flows, including a dummy variable for the Arab Spring, which was also interacted with the WGI for the exporters and importers (see tables A.3 and A.4 in the Appendix). The interaction term was statistically significant for three out of the six WGI indicators, showing that after the Arab Spring the importance of voice and accountability as a determinant of MENA exports has increased, whereas the importance of political stability and rule of law has decreased.

\footnotetext{
${ }^{7}$ We also tried to estimate other specifications with PPML but the model did not converge.
} 


\section{Conclusions and Policy Implications}

This research evaluates the importance of governance for promoting trade and the integration of MENA exporters into the global economy. The main results indicate that the governance in exporters and importers matters for bilateral export flows in general, and for MENA countries in particular. Interestingly, we find that MENA countries trade more with countries that have similar levels of regulatory quality and rule of law. When MENA exports are sent to other MENA countries, an increase in an exporter's government effectiveness, rule of law and the control of corruption in the trading countries increases MENA exports. The results also indicate that after the Arab Spring, the importance of voice and accountability -as a determinant of MENA exports- has increased, whereas the importance of political stability and rule of law have decreased. The main economic policy implications are the prerequisites for a good business environment at the country-level, which include the protection of property rights, a well-established rule of law, efficient bureaucracy and a corruption-free government. An improvement in the governance of MENA countries is therefore essential to develop a favourable business climate and to enter a path of economic development and integration into the world economy. Moreover, the results indicate that having similar levels of regulatory quality and rule of law, favours the exports of MENA countries; hence, trade policies to liberalize trade should focus on trading partners with similar governance standards for those two governance indicators. 


\section{References}

Acemoglu, D., Johnson, S., Robinson, J. and Thaicharoen, Y. (2003) Institutional Causes, Macroeconomic Symptoms: Volatility, Crises and Growth, Journal of Monetary Economics, Vol. 50, No. 1, pp. 49-123,

Acemoglu, D., Johnson, S., and Robinson, J.A (2002), Reversal of Fortune: Geography and Institutions in the Making of the Modern World Income Distribution, Quarterly Journal of Economics, Vol. 107, No. 4, pp. 1231-1294.

Acemoglu, D., Johnson, S., and Robinson, J.A., (2001) The Colonial Origins of Comparative Development: An Empirical Investigation, American Economic Review, Vol. 91, No. 5, pp. 1369-1401.

Alamá-Sabater, L., Heid, B., Jiménez-Fernández, E., \& Márquez-Ramos, L. (2016). What Drives Interdependence of FDI among Host Countries? The Role of Geographic Proximity and Similarity in Public Debt. Economic Modelling 58, 466-474.

Ali, M. S. B., \& Mdhillat, M. (2015). Does Corruption Impede International Trade? New evidence from The EU and the MENA Countries. Journal of Economic Cooperation and Development, 36(4), 107-120.

Anderson, J. E. (2010). The gravity model (No. w16576). National Bureau of Economic Research.

Anderson, J. E., \& van Wincoop, E. (2003). Gravity with Gravitas: A Solution to the Border Puzzle. American Economic Review 93(1), 170-192.

Baier, S. L., \& Bergstrand, J. H. (2007). Do free trade agreements actually increase members' international trade? Journal of international Economics, 71(1), 72-95.

Baier, S. L., Bergstrand, J. H. and Feng, M. (2014). Economic integration agreements and the margins of international trade, Journal of International Economics, 93(2), 339350. 
Berden, K., Bergstrand, J. H., \& Etten, E. (2014). Governance and globalisation. The World Economy, 37(3), 353-386.

Botero, J. C., Djankov, S., R. La Porta, F. Lopez-de-Silanes, and A. Shleifer, (2002).

The Regulation of Labour, Quarterly Journal of Economics 119(4), 1339-1382.

Djankov, S., R. La Porta, F. Lopez-de-Silanes, and A. Shleifer, (2002). The Regulation of Entry, Quarterly Journal of Economics, CXVII, 1-37.

Doyle, E., \& Martínez-Zarzoso, I. (2011). Productivity, Trade and Institutional Quality: A Panel Analysis. Southern Economic Journal 77 (3), 726-752.

Easterly, W., (2001). The Middle Class Consensus And Economic Development, Journal of Economic Growth 6 (4), pp. 317-335.

Feenstra, R. (2004). Advanced International Trade. Theory and Evidence. Princeton University Press, Princeton, New Jersey.

Gylfason, T., Martínez-Zarzoso, I., \& Wijkman, P. M. (2015). Free Trade Agreements, Institutions and the Exports of Eastern Partnership Countries. Journal of Common Market Studies 53 (6), 1214-1229.

Hall, R.E. and Jones, C.I. (1999) Why Do Some Countries Produce So Much Output per Worker than Others? Quarterly Journal of Economics 114 (1), 83-116.

Head, K., \& Mayer, T. (2014), "Gravity equations: Workhorse, toolkit, and cookbook," in Gopinath, G., E. Helpman and K. Rogoff (eds.): Handbook of International Economics, Vol. 4, 131-195, Amsterdam, Elsevier-North Holland.

Horsewood, N., \& Voicu, A. M. (2012). Does corruption hinder trade for the new EU members? Economics: The Open-Access, Open-Assessment E-Journal, 6(47), 1-28.

Kaufmann, D., Kraay, A., \& Mastruzzi, M. (2007). Governance Matters VI: Aggregate and Individual Governance Indicators, 1996-2006. World Bank Policy Research Working Paper No. 4280 (Washington, DC: World Bank). 
Kaufmann, D., Kraay, A. \& Mastruzzi, M. (2010). The Worldwide Governance Indicators: A Summary of Methodology, Data and Analytical Issues". World Bank Policy Research Working Paper No. 5430 (Washington, DC: World Bank).

La Porta, R., Lopez-De-Silanes, F., Shleifer, A. \& Vishny, R. (1997), Legal Determinants of External Finance, Journal Of Finance, Vol. 52, No. 3, pp.1131-1150.

La Porta, R., Lopez-De-Silanes, F., Shleifer, A. \& Vishny, R. (1998), Law And Finance, Journal of Political Economy 106, 6, 1113-1155.

Levchenko, A.A. (2007). "Institutional Quality and International Trade" Review of Economic Studies 74 (3), 791-819.

Márquez-Ramos, L., Martínez-Zarzoso, I. \& Suárez-Burguet, C. (2012), “Trade Policy versus Trade Facilitation: An Application Using "Good Old" OLS” Economics: The Open-Access, Open-Assessment E-Journal. 6, 2012-11.

http://dx.doi.org/10.5018/economics-ejournal.ja.2012-11.

Martínez-Zarzoso, I. (2013). The log of gravity revisited. Applied Economics, 45(3), 311-327.

Martínez-Zarzoso, I., Nowak-Lehmann D., F. \& Horsewood, N. (2009). Are Regional Trading Agreements Beneficial? Static and Dynamic Panel Gravity Models. North American Journal of Economics and Finance 20, 46-65.

Martínez-Zarzoso, I., Nowak-Lehman D., F. and Klasen, S. (2016) "Aid and its Impact on the Donor's Export Industry- The Dutch Case", European Journal of Development Research, forthcoming.

Méon, P. G., \& Sekkat, K. (2004). Does the quality of institutions limit the MENA's integration in the world economy? The World Economy, 27(9), 1475-1498. 
Milner H., \& Kubota K. (2005). Why the move to free trade? Democracy and trade policy in the developing countries. International Organizations. 59, 107-43.

Milner, H. V. \& B. Mukherjee (2009). Democratization and Economic Globalization, Annual Review of Political Science, 12, 163-81.

Nunn, N. \& Trefler, D. (2014). "Domestic Institutions as a Source of Comparative Advantage," in Gopinath, G., E. Helpman and K. Rogoff (eds.): Handbook of International Economics 4, 263-315, Amsterdam, Elsevier-North Holland.

Sachs J. D. \& Warner, A. M. (1995). "Economic Reform and the Process of Global Integration," Brookings Papers on Economic Activity, Economic Studies Program, The Brookings Institution 26 (1, 25th A), 1-118.

Sachs J. D. \& Warner, A. M., (1999). "The big push, natural resource booms and growth," Journal of Development Economics 59(1), 43-76.

Sachs J. D. \& Warner, A. M. (2001). "The curse of natural resources," European Economic Review 45(4-6), 827-838.

Wikipedia (2016). Arab Spring, available at https://en.wikipedia.org/wiki/Arab_Spring, retrieved 30 May 2016.

Yu, M. (2010). Trade, Democracy, and the Gravity Equation, Journal of Development Economics, 91,2, 289-300. 


\section{Appendix A}

\section{Table A.1. List of countries}

\begin{tabular}{|c|c|c|c|}
\hline Afghanistan & Dominican Rep. & Libya & Singapore \\
\hline Albania & Ecuador & Lithuania & Slovakia \\
\hline Algeria & Egypt & Madagascar & Slovenia \\
\hline Angola & El Salvador & Malawi & Solomon Isds \\
\hline Antigua and Barbuda & Equatorial Guinea & Malaysia & Somalia \\
\hline Argentina & Eritrea & Maldives & South Africa \\
\hline Armenia & Estonia & Mali & Spain \\
\hline Australia & Ethiopia & Malta & Sri Lanka \\
\hline Austria & FS Micronesia & Marshall Isds & Sudan \\
\hline Azerbaijan & Faeroe Isds & Mauritania & Suriname \\
\hline Bahamas & Fiji & Mauritius & Swaziland \\
\hline Bahrain & Finland & Mexico & Sweden \\
\hline Bangladesh & France & Mongolia & Switzerland \\
\hline Barbados & French Polynesia & Morocco & Syria \\
\hline Belarus & Gabon & Mozambique & TFYR of Macedonia \\
\hline Belgium & Gambia & Myanmar & Tajikistan \\
\hline Belize & Georgia & Namibia & Thailand \\
\hline Benin & Germany & Nepal & Togo \\
\hline Bermuda & Ghana & Netherlands & Tonga \\
\hline Bhutan & Greece & New Caledonia & Trinidad and Tobago \\
\hline Bolivia & Greenland & New Zealand & Tunisia \\
\hline Bosnia Herzegovina & Grenada & Nicaragua & Turkey \\
\hline Botswana & Guatemala & Niger & Turkmenistan \\
\hline Brazil & Guinea & Nigeria & Turks and Caicos Isds \\
\hline Brunei Darussalam & Guinea-Bissau & Norway & Tuvalu \\
\hline Bulgaria & Guyana & Oman & USA \\
\hline Burkina Faso & Haiti & Pakistan & Uganda \\
\hline Burundi & Honduras & Palau & Ukraine \\
\hline Cambodia & Hungary & Panama & United Arab Emirates \\
\hline Cameroon & Iceland & Papua New Guinea & United Kingdom \\
\hline Canada & India & Paraguay & United Rep. of Tanzania \\
\hline Cape Verde & Indonesia & Peru & Uruguay \\
\hline Cayman Isds & Iran & Philippines & Uzbekistan \\
\hline Central African Rep. & Iraq & Poland & Vanuatu \\
\hline Chad & Ireland & Portugal & Venezuela \\
\hline Chile & Israel & Qatar & Viet Nam \\
\hline China & Italy & Rep. of Korea & Yemen \\
\hline Colombia & Jamaica & Rep. of Moldova & Zambia \\
\hline Comoros & Japan & Russian Federation & Zimbabwe \\
\hline Congo & Jordan & Rwanda & \\
\hline Costa Rica & Kazakhstan & Saint Kitts and Nevis & \\
\hline Croatia & Kenya & Saint Lucia & \\
\hline Cuba & Kiribati & Saint Vincent and the Grenadines & \\
\hline Cyprus & Kuwait & Samoa & \\
\hline Czech Rep. & Kyrgyzstan & San Marino & \\
\hline Côte d'Ivoire & Lao People's Dem. Rep. & Sao Tome and Principe & \\
\hline Dem. People's Rep. of Korea & Latvia & Saudi Arabia & \\
\hline Denmark & Lebanon & Senegal & \\
\hline Djibouti & Lesotho & Seychelles & \\
\hline Dominica & Liberia & Sierra Leone & \\
\hline
\end{tabular}


Table A.2. PPML estimations of the gravity model for all countries with countrypair FE

\begin{tabular}{|c|c|c|c|c|c|c|}
\hline VARIABLES & (1) & (2) & (3) & (4) & (5) & (6) \\
\hline InGDP_it & $\begin{array}{c}0.590 * * * \\
{[0.0311]}\end{array}$ & $\begin{array}{c}0.597 * * * \\
{[0.0307]}\end{array}$ & $\begin{array}{c}0.589 * * * \\
{[0.0312]}\end{array}$ & $\begin{array}{c}0.590 * * * \\
{[0.0314]}\end{array}$ & $\begin{array}{c}0.581 * * * \\
{[0.0315]}\end{array}$ & $\begin{array}{c}0.592 * * * \\
{[0.0311]}\end{array}$ \\
\hline InGDP_jt & $\begin{array}{c}0.634 * * * \\
{[0.0315]}\end{array}$ & $\begin{array}{c}0.645^{* * *} \\
{[0.0340]}\end{array}$ & $\begin{array}{c}0.628 * * * \\
{[0.0330]}\end{array}$ & $\begin{array}{c}0.626 * * * \\
{[0.0323]}\end{array}$ & $\begin{array}{c}0.637^{* * *} \\
{[0.0338]}\end{array}$ & $\begin{array}{c}0.633 * * * \\
{[0.0320]}\end{array}$ \\
\hline RTA & $\begin{array}{c}0.0646^{* *} \\
{[0.0289]}\end{array}$ & $\begin{array}{c}0.0612 * * \\
{[0.0309]}\end{array}$ & $\begin{array}{l}0.0539 * \\
{[0.0291]}\end{array}$ & $\begin{array}{c}0.0619 * * \\
{[0.0288]}\end{array}$ & $\begin{array}{c}0.0647^{* *} \\
{[0.0296]}\end{array}$ & $\begin{array}{c}0.0614^{* *} \\
{[0.0292]}\end{array}$ \\
\hline WTO & $\begin{array}{c}0.250 * * * \\
{[0.0340]}\end{array}$ & $\begin{array}{c}0.231 * * * \\
{[0.0345]}\end{array}$ & $\begin{array}{c}0.232 * * * \\
{[0.0322]}\end{array}$ & $\begin{array}{c}0.245 * * * \\
{[0.0332]}\end{array}$ & $\begin{array}{c}0.242 * * * \\
{[0.0328]}\end{array}$ & $\begin{array}{c}0.245 * * * \\
{[0.0330]}\end{array}$ \\
\hline VAstd_it & $\begin{array}{c}1.77 e-05 \\
{[0.00218]}\end{array}$ & & & & & \\
\hline VAstd_jt & $\begin{array}{c}0.00399 * * \\
{[0.00178]}\end{array}$ & & & & & \\
\hline PSstd_it & & $\begin{array}{c}0.00327^{* * *} \\
{[0.000979]}\end{array}$ & & & & \\
\hline PSstd_jt & & $\begin{array}{c}0.00106 \\
{[0.000842]}\end{array}$ & & & & \\
\hline GEstd_it & & & $\begin{array}{c}0.00111 \\
{[0.00189]}\end{array}$ & & & \\
\hline GEstd_jt & & & $\begin{array}{c}0.00430 * * * \\
{[0.00156]}\end{array}$ & & & \\
\hline RQstd_it & & & & $\begin{array}{c}0.00257 \\
{[0.00217]}\end{array}$ & & \\
\hline RQstd_jt & & & & $\begin{array}{c}0.00684^{* * *} \\
{[0.00181]}\end{array}$ & & \\
\hline RLstd_it & & & & & $\begin{array}{c}0.00496 * * \\
{[0.00241]}\end{array}$ & \\
\hline RLstd_jt & & & & & $\begin{array}{c}0.00135 \\
{[0.00162]}\end{array}$ & \\
\hline CCstd_it & & & & & & $\begin{array}{l}-0.000663 \\
{[0.00157]}\end{array}$ \\
\hline CCstd_jt & & & & & & $\begin{array}{c}0.00371^{* *} \\
{[0.00151]}\end{array}$ \\
\hline Pair FE & Yes & Yes & Yes & Yes & Yes & Yes \\
\hline Year FE & Yes & Yes & Yes & Yes & Yes & Yes \\
\hline $\begin{array}{l}\text { Observations } \\
\text { Number of }\end{array}$ & 356,573 & 327,133 & 353,384 & 353,630 & 356,573 & 353,384 \\
\hline pairid & 24,262 & 24,082 & 24,159 & 24,163 & 24,262 & 24,159 \\
\hline
\end{tabular}

Note: Robust standard errors in brackets. $* * * \mathrm{p}<0.01, * * \mathrm{p}<0.05, * \mathrm{p}<0.1$. Governance indicators: VA: Voice and Accountability; PS: Political Stability; GE: Government Effectiveness; RQ: Regulatory Quality; RL: Rule of Law and CC: Control of Corruption; std indicate standardized values (0-100). 
Table A.3. Starting dates for the Arab Spring, by MENA country

\begin{tabular}{|c|c|}
\hline Country & Date started \\
\hline Tunisia & 18 December 2010 \\
\hline Algeria & 29 December 2010 \\
\hline Jordan & 14 January 2011 \\
\hline Oman & 17 January 2011 \\
\hline Egypt & 25 January 2011 \\
\hline Syria & 26 January 2011 \\
\hline Yemen & 27 January 2011 \\
\hline Djibouti & 28 January 2011 \\
\hline Somalia & 28 January 2011 \\
\hline Sudan & 30 January 2011 \\
\hline Palestinian Authority & 10 February 2011 \\
\hline Iraq & 12 February 2011 \\
\hline Bahrain & 14 February 2011 \\
\hline Libya & 17 February 2011 \\
\hline Kuwait & 19 February 2011 \\
\hline Morocco & 20 February 2011 \\
\hline Mauritania & 25 February 2011 \\
\hline Lebanon & 27 February 2011 \\
\hline Saudi Arabia & 11 March 2011 \\
\hline Iranian Khuzestan & 15 April 2011 \\
\hline Borders of Israel & 15 May 2011 \\
\hline
\end{tabular}

Source: Wikipedia (2016). 
Table A.4. Changes in the coefficients after the Arab Spring, MENA exporters

\begin{tabular}{|c|c|c|c|c|c|c|}
\hline VARIABLES & $\begin{array}{c}(1) \\
\text { Govij }\end{array}$ & $\begin{array}{c}\text { (2) } \\
\text { Govij }\end{array}$ & $\begin{array}{c}\text { (3) } \\
\text { Govij }\end{array}$ & $\begin{array}{c}\text { (4) } \\
\text { Govij }\end{array}$ & $\begin{array}{c}\text { (5) } \\
\text { Govij }\end{array}$ & $\begin{array}{c}(6) \\
\text { Govij }\end{array}$ \\
\hline RTA & $\begin{array}{c}0.279 * * * \\
{[0.0749]}\end{array}$ & $\begin{array}{c}0.297 * * * \\
{[0.0769]}\end{array}$ & $\begin{array}{c}0.300 * * * \\
{[0.0750]}\end{array}$ & $\begin{array}{c}0.295 * * * \\
{[0.0748]}\end{array}$ & $\begin{array}{c}0.265^{* * *} \\
{[0.0746]}\end{array}$ & $\begin{array}{c}0.297^{* * *} \\
{[0.0746]}\end{array}$ \\
\hline WTO & $\begin{array}{c}0.268 * * * \\
{[0.0920]}\end{array}$ & $\begin{array}{c}0.294^{* * *} \\
{[0.0938]}\end{array}$ & $\begin{array}{c}0.281^{* * *} \\
{[0.0930]}\end{array}$ & $\begin{array}{c}0.271 * * * \\
{[0.0921]}\end{array}$ & $\begin{array}{c}0.263 * * * \\
{[0.0926]}\end{array}$ & $\begin{array}{c}0.271^{* * *} \\
{[0.0923]}\end{array}$ \\
\hline dumAS & $\begin{array}{c}-0.909 \\
{[0.896]}\end{array}$ & $\begin{array}{c}0.346 \\
{[0.945]}\end{array}$ & $\begin{array}{l}-0.508 \\
{[0.901]}\end{array}$ & $\begin{array}{l}-0.169 \\
{[0.952]}\end{array}$ & $\begin{array}{c}0.888 \\
{[0.915]}\end{array}$ & $\begin{array}{c}-0.198 \\
{[0.881]}\end{array}$ \\
\hline VAstd_ijt & $\begin{array}{c}-0.00963^{* * *} \\
{[0.00324]}\end{array}$ & & & & & \\
\hline VAstd_ijtAS & $\begin{array}{l}0.0167 * * \\
{[0.00733]}\end{array}$ & & & & & \\
\hline PSstd_ijt & & $\begin{array}{c}0.0114 * * * \\
{[0.00163]}\end{array}$ & & & & \\
\hline PSstd_ijtAS & & $\begin{array}{c}-0.00703^{*} \\
{[0.00418]}\end{array}$ & & & & \\
\hline GEstd_ijt & & & $\begin{array}{c}0.00563 \\
{[0.00397]}\end{array}$ & & & \\
\hline GEstd_ijtAS & & & $\begin{array}{c}0.00740 \\
{[0.00859]}\end{array}$ & & & \\
\hline RQstd_ijt & & & & $\begin{array}{c}0.00207 \\
{[0.00261]}\end{array}$ & & \\
\hline RQstd_ijtAS & & & & $\begin{array}{l}-0.000667 \\
{[0.00912]}\end{array}$ & & \\
\hline RLstd_ijt & & & & & $\begin{array}{c}0.0249 * * * \\
{[0.00312]}\end{array}$ & \\
\hline RLstd_ijtAS & & & & & $\begin{array}{c}-0.0212^{*} \\
{[0.0112]}\end{array}$ & \\
\hline CCstd_ijt & & & & & & $\begin{array}{c}0.00867^{* * *} \\
{[0.00234]}\end{array}$ \\
\hline CCstd_ijtAS & & & & & & $\begin{array}{c}0.00737 \\
{[0.00927]}\end{array}$ \\
\hline Pair FE & Yes & Yes & Yes & Yes & Yes & Yes \\
\hline iyear5, jyear5 FeE & Yes & Yes & Yes & Yes & Yes & Yes \\
\hline Observations & 24,619 & 22,709 & 24,594 & 24,596 & 24,619 & 24,594 \\
\hline R-squared & 0.249 & 0.260 & 0.249 & 0.249 & 0.251 & 0.250 \\
\hline Number of pairid & 2,804 & 2,786 & 2,793 & 2,793 & 2,804 & 2,793 \\
\hline
\end{tabular}

Note: Robust standard errors in brackets. ${ }^{* * *} p<0.01,{ }^{* *} p<0.05, * p<0.1$. Where AS is a dummy variable that takes the value of one after the Arab Spring started (See Table A.3), zero before. AS is interacted with each governance indicator: VA: Voice and Accountability; PS: Political Stability; GE: Government Effectiveness; RQ: Regulatory Quality; RL: Rule of Law and CC: Control of Corruption; std indicate standardized values (0-100). 


\section{Appendix B}

Table B.1. Gravity model estimates for governance indicators with time-variant MRT and country-pair FE: All countries

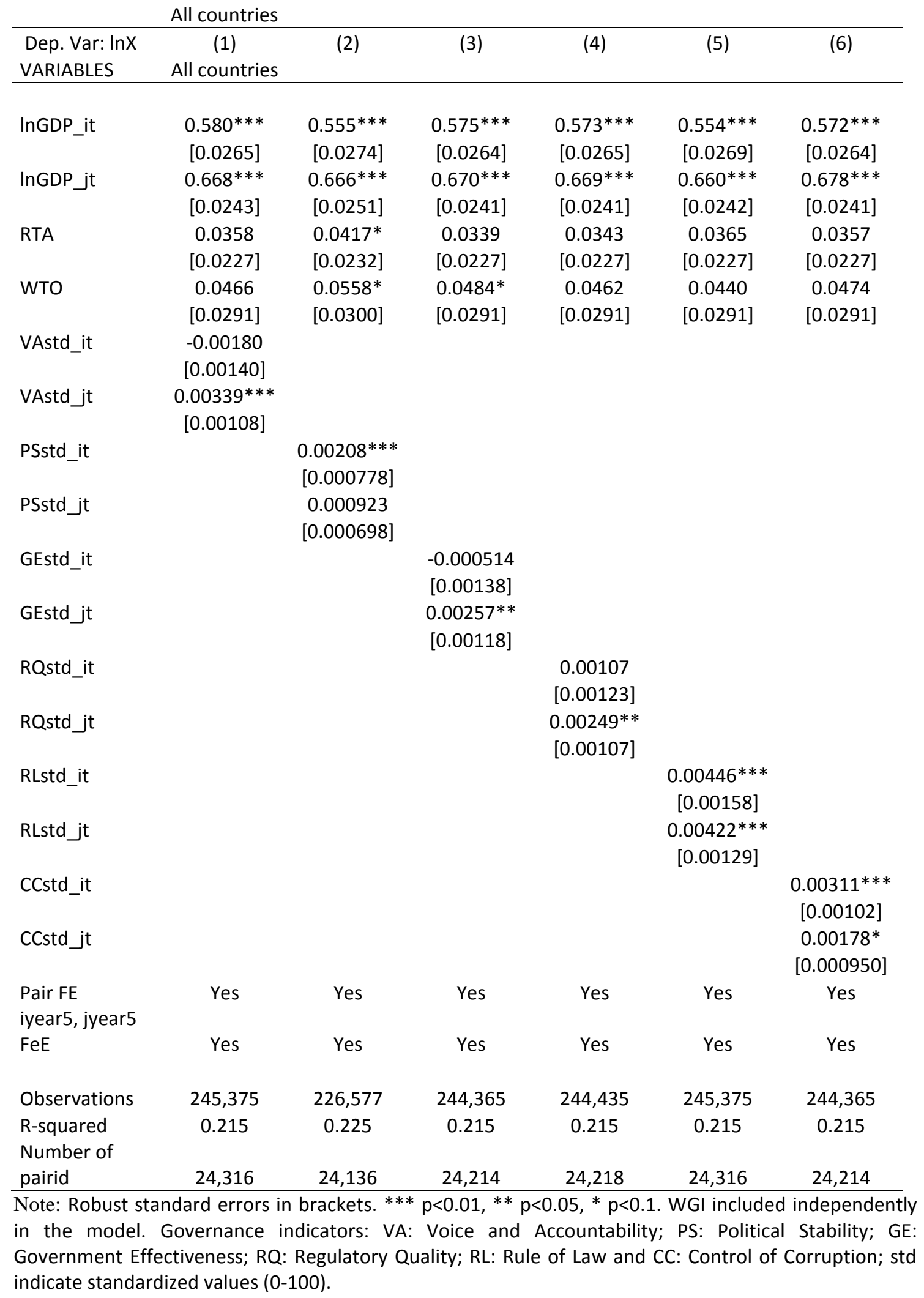


Table B.2. Gravity model estimates for governance indicators with time-variant MRT and country-pair FE: MENA exporters

\begin{tabular}{|c|c|c|c|c|c|c|}
\hline $\begin{array}{l}\text { Dep. Var: In X } \\
\text { VARIABLES }\end{array}$ & $\begin{array}{c}(1) \\
\text { MENA export }\end{array}$ & ers & (3) & (4) & (5) & (6) \\
\hline InGDP_it & $\begin{array}{c}0.927^{* * *} \\
{[0.0906]}\end{array}$ & $\begin{array}{c}0.759 * * * \\
{[0.0942]}\end{array}$ & $\begin{array}{c}0.905 * * * \\
{[0.0882]}\end{array}$ & $\begin{array}{c}0.897 * * * \\
{[0.0886]}\end{array}$ & $\begin{array}{c}0.844 * * * \\
{[0.0884]}\end{array}$ & $\begin{array}{c}0.855^{* * *} \\
{[0.0879]}\end{array}$ \\
\hline $\operatorname{lnGDP} j \mathrm{t}$ & $\begin{array}{c}0.528 * * * \\
{[0.0852]}\end{array}$ & $\begin{array}{c}0.613 * * * \\
{[0.0889]}\end{array}$ & $\begin{array}{c}0.534 * * * \\
{[0.0848]}\end{array}$ & $\begin{array}{c}0.529 * * * \\
{[0.0852]}\end{array}$ & $\begin{array}{c}0.509 * * * \\
{[0.0872]}\end{array}$ & $\begin{array}{c}0.623^{* * *} \\
{[0.0852]}\end{array}$ \\
\hline RTA & $\begin{array}{c}0.133^{*} \\
{[0.0750]}\end{array}$ & $\begin{array}{c}0.142^{*} \\
{[0.0770]}\end{array}$ & $\begin{array}{c}0.141^{*} \\
{[0.0748]}\end{array}$ & $\begin{array}{c}0.130 * \\
{[0.0747]}\end{array}$ & $\begin{array}{c}0.123^{*} \\
{[0.0747]}\end{array}$ & $\begin{array}{c}0.139 * \\
{[0.0745]}\end{array}$ \\
\hline WTO & $\begin{array}{c}0.0384 \\
{[0.0934]}\end{array}$ & $\begin{array}{c}0.0765 \\
{[0.0949]}\end{array}$ & $\begin{array}{c}0.0731 \\
{[0.0937]}\end{array}$ & $\begin{array}{c}0.0507 \\
{[0.0930]}\end{array}$ & $\begin{array}{c}0.0638 \\
{[0.0930]}\end{array}$ & $\begin{array}{c}0.0234 \\
{[0.0930]}\end{array}$ \\
\hline VAstd_it & $\begin{array}{c}0.0142^{* * *} \\
{[0.00469]}\end{array}$ & & & & & \\
\hline VAstd_jt & $\begin{array}{l}-0.000210 \\
{[0.00405]}\end{array}$ & & & & & \\
\hline PSstd_it & & $\begin{array}{c}0.00944 * * * \\
{[0.00256]}\end{array}$ & & & & \\
\hline PSstd_jt & & $\begin{array}{c}-0.00190 \\
{[0.00259]}\end{array}$ & & & & \\
\hline GEstd_it & & & $\begin{array}{c}0.0179 * * * \\
{[0.00578]}\end{array}$ & & & \\
\hline GEstd_jt & & & $\begin{array}{c}0.00339 \\
{[0.00495]}\end{array}$ & & & \\
\hline RQstd_it & & & & $\begin{array}{l}0.000193 \\
{[0.00431]}\end{array}$ & & \\
\hline RQstd_tt & & & & $\begin{array}{l}0.000137 \\
{[0.00418]}\end{array}$ & & \\
\hline RLstd_it & & & & & $\begin{array}{c}0.0185^{* * *} \\
{[0.00501]}\end{array}$ & \\
\hline RLstd_jt & & & & & $\begin{array}{c}-0.00181 \\
{[0.00510]}\end{array}$ & \\
\hline CCstd_it & & & & & & $\begin{array}{c}0.0218^{* * *} \\
{[0.00312]}\end{array}$ \\
\hline CCstd_jt & & & & & & $\begin{array}{c}0.00131 \\
{[0.00357]}\end{array}$ \\
\hline Pair FE & Yes & Yes & Yes & Yes & Yes & Yes \\
\hline it5,jt5 & yes & yes & yes & yes & yes & yes \\
\hline Observations & 23,672 & 21,768 & 23,654 & 23,656 & 23,672 & 23,654 \\
\hline R-squared & 0.267 & 0.275 & 0.267 & 0.267 & 0.267 & 0.269 \\
\hline Number of pairid & 2,744 & 2,719 & 2,734 & 2,734 & 2,744 & 2,734 \\
\hline
\end{tabular}


Table B.3. Gravity model estimates for governance indicators with time-variant MRT and country-pair FE: Intra-MENA trade

\begin{tabular}{|c|c|c|c|c|c|c|}
\hline \multirow[b]{2}{*}{ VARIABLES } & \multicolumn{6}{|c|}{ INTRA MENA TRADE } \\
\hline & $\begin{array}{c}(1) \\
\text { All countries } \\
\end{array}$ & (2) & (3) & (4) & (5) & (6) \\
\hline InGDP_it & $\begin{array}{c}0.694 * * * \\
{[0.155]}\end{array}$ & $\begin{array}{c}0.571^{* * *} \\
{[0.180]}\end{array}$ & $\begin{array}{c}0.643 * * * \\
{[0.155]}\end{array}$ & $\begin{array}{c}0.616 * * * \\
{[0.159]}\end{array}$ & $\begin{array}{c}0.564 * * * \\
{[0.154]}\end{array}$ & $\begin{array}{c}0.598 * * * \\
{[0.156]}\end{array}$ \\
\hline InGDP_jt & $\begin{array}{c}0.634 * * * \\
{[0.139]}\end{array}$ & $\begin{array}{c}0.719 * * * \\
{[0.158]}\end{array}$ & $\begin{array}{c}0.674 * * * \\
{[0.137]}\end{array}$ & $\begin{array}{c}0.695^{* * *} \\
{[0.140]}\end{array}$ & $\begin{array}{c}0.647^{* * *} \\
{[0.142]}\end{array}$ & $\begin{array}{c}0.762 * * * \\
{[0.140]}\end{array}$ \\
\hline RTA & $\begin{array}{l}0.217^{* *} \\
{[0.0965]}\end{array}$ & $\begin{array}{c}0.167^{*} \\
{[0.0986]}\end{array}$ & $\begin{array}{l}0.227 * * \\
{[0.0964]}\end{array}$ & $\begin{array}{c}0.192 * \\
{[0.0983]}\end{array}$ & $\begin{array}{l}0.192 * * \\
{[0.0947]}\end{array}$ & $\begin{array}{c}0.156^{*} \\
{[0.0944]}\end{array}$ \\
\hline WTO & $\begin{array}{c}-0.00883 \\
{[0.115]}\end{array}$ & $\begin{array}{l}0.0242 \\
{[0.115]}\end{array}$ & $\begin{array}{l}0.0150 \\
{[0.116]}\end{array}$ & $\begin{array}{c}0.00289 \\
{[0.116]}\end{array}$ & $\begin{array}{c}0.00239 \\
{[0.118]}\end{array}$ & $\begin{array}{c}-0.0248 \\
{[0.115]}\end{array}$ \\
\hline VAstd_it & $\begin{array}{c}0.00762 \\
{[0.00857]}\end{array}$ & & & & & \\
\hline VAstd_jt & $\begin{array}{c}0.0118 \\
{[0.00728]}\end{array}$ & & & & & \\
\hline PSstd_it & & $\begin{array}{l}0.000246 \\
{[0.00534]}\end{array}$ & & & & \\
\hline PSstd_jt & & $\begin{array}{c}-0.00292 \\
{[0.00488]}\end{array}$ & & & & \\
\hline GEstd_it & & & $\begin{array}{c}0.0253 * * \\
{[0.0108]}\end{array}$ & & & \\
\hline GEstd_jt & & & $\begin{array}{c}0.00165 \\
{[0.00888]}\end{array}$ & & & \\
\hline RQstd_it & & & & $\begin{array}{c}0.00679 \\
{[0.00837]}\end{array}$ & & \\
\hline RQstd_jt & & & & $\begin{array}{c}-0.0100 \\
{[0.00687]}\end{array}$ & & \\
\hline RLstd_it & & & & & $\begin{array}{c}0.0396 * * * \\
{[0.00950]}\end{array}$ & \\
\hline RLstd_jt & & & & & $\begin{array}{c}-0.0180 * * \\
{[0.00841]}\end{array}$ & \\
\hline CCstd_it & & & & & & $\begin{array}{c}0.0224 * * * \\
{[0.00570]}\end{array}$ \\
\hline CCstd_jt & & & & & & $\begin{array}{c}0.00204 \\
{[0.00559]}\end{array}$ \\
\hline Pair FE & Yes & Yes & Yes & Yes & Yes & Yes \\
\hline iyear5, jyear5 FE & Yes & Yes & Yes & Yes & Yes & Yes \\
\hline Observations & 3,441 & 3,168 & 3,441 & 3,441 & 3,441 & 3,441 \\
\hline R-squared & 0.442 & 0.445 & 0.443 & 0.442 & 0.446 & 0.445 \\
\hline Number of pairid & 329 & 325 & 329 & 329 & 329 & 329 \\
\hline
\end{tabular}

